\title{
Menstimulus Kemampuan Konstruksi Dan Eksplanasi Siswa Melalui Kombinasi Hands On Method Dan Flipped Classroom Pada Materi Gerak Lurus
}

\author{
Silvia Nadiana, Ngia Masta, Emi Darnah, Hana Bintang \\ Program Studi Pendidikan Fisika Fakultas Keguruan dan Ilmu Pendidikan Universitas Kristen \\ Indonesia Jakarta; Jl. Mayjen Sutoyo no 02 Cawang, Jakarta Timur \\ Email : silviavia092@gmail.com
}

\begin{abstract}
The era of the industrial revolution 4.0 is an era where learning systems and science require innovative human resources. Therefore, the world of education is required to be able to evolve in the face of the industrial era 4.0, through a curriculum approach using the SCL (Student Centered Learning) method. SCL (Student Centered Learning) is a student-centered approach and is characterized by student activity in constructing and expanding their knowledge. Hands On Method integration (experiment based) in Flipped Classroom will motivate students to learn. This study aims to improve the students' construction and explanation skills through learning that applies a combination of Hands On Method and Flipped Classroom on straight motion material. The study was conducted at SMAN 37 Jakarta, using a quasi-experimental method with the Post-test Only Control Design research design. The population in this study were all students of class X MIPA SMA 37 Jakarta. Samples were taken by the control class (35 students of class X MIPA 2) and the experimental class (35 students of class X MIPA 4). Students in the experimental class were given treatment in the form of applying a combination of Hands On Method and Flipped Classroom on straight motion material. The results showed the average results of students' construction and explanation abilities in the experimental class with the application of the Learning model through a combination of hands on method and flipped increased by 83,57, with a maximum score of 100. Whereas for the control class with conventional methods was 77,85, with a maximum score of 90 . This can also be seen from the graph of the percentage of students' answers to the ability of construction to increase by $85.7 \%$ and to the ability of expectations by $71.43 \%$.
\end{abstract}

Keywords: Construction Ability, Exploration Ability, Hands On Method and Flipped Classroom

\begin{abstract}
Abstrak: Era revolusi industry 4.0 adalah Era dimana sistem pembelajaran dan ilmu pengetahuan membutuhkan sumber daya manusia yang inovatif. Karena itu, dunia pendidikan dituntut harus mampu berevolusi dalam menghadapi era industri 4.0, melalui sebuah pendekatan kurikulum menggunakan metode SCL (Student Centered Learning). Integrasi Hands On Method (berbasis eksperimen) pada Flipped Classroom akan memotivasi siswa dalam belajar. Penelitian ini bertujuan untuk meningkatkan kemampuan konstruksi dan eksplanasi siswa melalui pembelajaran yang menerapkan kombinasi Hands On Method dan Flipped Classroom pada materi gerak lurus. Penelitian ini menggunakan metode kuasi eksperimen dengan desain penelitian Post-test Only Control Design. Populasi dalam penelitian ini adalah seluruh siswa kelas X MIPA SMA Negeri 37 Jakarta. Sampel yang diambil kelas control (35 orang siswa kelas X MIPA 2) dan kelas eksperimen (35 siswa kelas X MIPA 4). Siswa pada kelas eksperimen diberi perlakuan berupa penerapan kombinasi Hands On Method dan Flipped Classroom pada materi gerak lurus. Hasil penelitian menunjukkan rata-rata hasil kemampuan konstruksi dan eksplanasi siswa pada kelas eksperimen dengan penerapan model Pembelajaran melalui kombinasi hands on method dan flipped meningkat sebesar 83,57, dengan skor maksimum 100. Sedangkan untuk kelas kontrol dengan metode konvensional sebesar 77,85, dengan skor maksimum 90. Ini dapat dilihat pula dari grafik presentase jawaban siswa pada kemampuan konstruksi meningkat sebesar $85,7 \%$ dan untuk kemampuan ekplanasi sebesar 71,43\%.
\end{abstract}


Kata Kunci: Kemampuan Konstruksi, Kemampuan Eksplanasi, Hands On Method dan Flipped Classroom

\section{PENDAhuluan}

Pendidikan di era revolusi industri 4.0 merupakan cara untuk melengkapi fenomena integrasi digital dalam kehidupan sehari-hari di mana manusia dan mesin berinteraksi untuk memecahkan masalah dan menemukan teori inovasi baru. Dalam pendidikan 4.0, akses informasi tidak 2 terbatas ruang dan waktu serta proses belajar mengajar telah menjadi dinamis. Masa depan pendidikan 4.0 dapat mengubah pemanfaatan informasi dengan cara yang praktis dan berbasis digital. Untuk mengatasi kebutuhan revolusi industri 4.0 dalam pendidikan, lembaga pendidikan harus terus mengintegrasikan metode inovatif untuk meningkatkan proses belajar mengajar.(Wiyono \& Zakiyah, 2016)

SCL merupakan pendekatan pembelajaran yang berpusat pada siswa. Dalam pendekatan pembelajaran SCL, guru harus mampu melaksanakan perannya dengan baik yaitu tidak hanya sebagai pengajar, tetapi juga sebagai motivator, fasilitator, dan inovator. Guru tidak hanya dituntut untuk mengajar saja di depan kelas melainkan juga berperan membantu murid untuk memecahkan masalah saat murid mengalami kesulitan dalam proses pembelajaran. Natawijaya dalam Depdiknas (2005:31) menyebutkan bahwa belajar aktif adalah suatu sistem belajar mengajar yang menekankan keaktifan siswa secara fisik, mental intelektual dan emosional guna memperoleh hasil belajar berupa perpaduan antara aspek kognitif, afektif dan psikomotor. (Antika, 2014). Adapun tujuan yang ingin dicapai dari proses pembelajaran yang berpusat pada siswa menurut Trinova (2013) adalah siswa diharapkan mampu memiliki keleluasaan untuk berperan aktif dan mandiri untuk membangun pengetahuan serta mencapai kompetensinya dengan sumber-sumber informasi yang diperolehnya sendiri melalui proses pembelajaran aktif, interaktif, kolaboratif, dan kooperatif. (Yanah, Nyeneng, \& Suana, 2018)

Metode pembelajaran Hands On Minds On adalah suatu metode pembelajaran yang dirancang untuk melibatkan peserta didik dalam menggali informasi dengan bertanya, beraktivitas dan menemukan, mengumpulkan data dan menganalisis serta membuat kesimpulan. Hands-on activity didefinisikan sebagai pendekatan instruksional yang melibatkan aktivitas dan pengalaman langsung dengan fenomena alam atau pengalaman pendidikan yang secara aktif melibatkan siswa dalam memanipulasi objek untuk mendapatkan pengetahuan atau pemahaman. Hands-on activity merupakan kegiatan eksperimen siswa untuk menemukan pengetahuan secara langsung melalui pengalaman sendiri, mengonstruksi pemahaman dan pengertian pengetahuan. Minds on activity adalah aktivitas berpusat pada konsep inti, dalam hal ini siswa mengembangkan proses berpikir (secara mental) untuk menjawab pertanyaanpertanyaan dalam menemukan konsep pengetahuan dan memahami pada kehidupan sehari-hari. (Rusmania, 2015)

Flipped classroom merupakan salah satu model pembelajaran yang baru dan masih sangat jarang digunakan. Urutan proses pembelajaran terbalik dari pembelajaran konvensional dimana mahasiswa diberikan penugasan di rumah sebagai persiapan perkuliahan. Di dalam kelas mahasiswa akan mengaplikasikan pembelajaran aktif yang dibimbing oleh tenaga pendidik. Terdapat 4 pillar model pembelajaran Flipped classroom yaitu Flexible Environment, Learning Culture, Intentional Content, dan Professional Educator (Hamden et al., 2013). Berdasarkan teori Bloom's taxonomy tahapan Flipped classroom pada proses mengingat pada materi baru diperkenalkan siswa di luar kelas sebagai pekerjaan rumah mereka. Sedangkan tahapan menerapkan, menganalisis, mengevaluasi, dan menciptakan dilakukan oleh mahasiswa dan tenaga pendidik dalam proses pembelajaran di kelas(Wulansari \& Sutrisna, 2018)

Adapun desain proses pembelajaran Flipped Classroom secara umum menurut 
Sihaloho (2017) adalah pembelajaran diawali dengan menonton video pembelajaran secara mandiri di rumah ditemani dengan LKPD pendamping video untuk memastikan peserta didik mengikuti pembelajaran mandiri non tatap muka. Pembelajaran tatap muka di kelas berupa tanya jawab mengenai soal-soal yang ada di LKPD pendamping video dan dilanjutkan dengan diskusi dengan LKPD lain yang memuat kegiatan percobaan, pengamatan, dan latihan soal.(Yanah et al., 2018)

Marpaung (2002) menyatakan bahwa konstruktivisme merupakan suatu teori atau faham yang menyatakan bahwa setiap pengetahuan atau kemampuan hanya bias dikuasai oleh seseorang apabila orang itu secara aktif mengkonstruksi (membentuk) pengetahuan atau kemampuan itu dalam pikirannya. Menurut Kauchack dan Eggen, (dalam Machmud, 2009) seseorang yang belajar hanya bisa mengerti apabila menggunakan pemahaman sebelumnya untuk memahami pengetahuan yang dipelajarinya dan membentuk pemahaman baru dari pengetahuan yang dipelajari itu, sehingga pemahamannya berkembang. Artinya, perkembangan pengetahuan hanya terjadi apabila dalam belajar itu terbentuk pemahaman, karena belajar itu sendiri merupakan upaya untuk memahami apa yang dipelajari. (Dedy Setyawan, 2013)

Pemahaman konsep merupakan kemampuan siswa dalam menguasai suatu konsep materi yang terindikasi dalam ranah kognitif. Dengan memahami suatu konsep siswa dapat mengetahui, menjelaskan, mendeskripsikan, membandingkan, membedakan, menggolongkan, memberikan contoh dan bukan contoh, menyimpulkan dan mengungkapkan kembali suatu objek dengan bahasanya sendiri dengan menyadari proses-proses yang dilaluinya. Dalam pembelajaran matematika di kelas, seringkali kurang menanamkan kemampuan berfikir sehingga siswa masih belum sepenuhnya memahami konsep seutuhnya. (Widyastuti, Pujiastuti, \& Yogyakarta, 2014)

Beberapa penelitian menggunakan model Flipped Classroom mengungkapkan adanya pengaruh saat menerapkan model pembelajaran ini di kelas, berdasarkan penelitian yang dilakukan oleh Rindaningsih (2018) menunjukkan bahwa pembelajaran Flipped Classroom berpengaruh kuat dalam mengasah keterampilan mahasiswa dan menjadikan siswa memiliki kesadaran dan tanggung jawab yang tinggi dalam berpartisipasi mengikuti kegiatan pembelajaran. Sedangkan menurut (Yanah et al., 2018) model pembelajaran Flipped Classroom dapat meningkatkan self efficacy dan kemampuan penguasaan konsep siswa.

Peneliti memilih SMA Negeri 37 Jakarta kerana jumlah siswanya lebih banyak, ada siswa yang masih kurang aktif dalam belajar serta guru fisika jarang melakukan eksperimen di laboratorium. Model pembelajaran Flipped Classroom belum diterapkan di SMA tersebut.

Berdasarkan uraian diatas, maka dilakukanlah sebuah penelitian untuk meningkatkan kemampuan konstruksi dan eksplanasi siswa melalui pembelajaran yang menerapkan kombinasi Hands On Method dan Flipped Classroom pada materi gerak lurus.

\section{METODE PENELITIAN}

Penelitian ini dilakukan di SMA Negeri 37 Jakarta pada saat PKM (Praktik Keterampilan Mengajar) berlangsung. Berikut gambar alur penelitian yang dilakukan dari awal sampai akhir. 


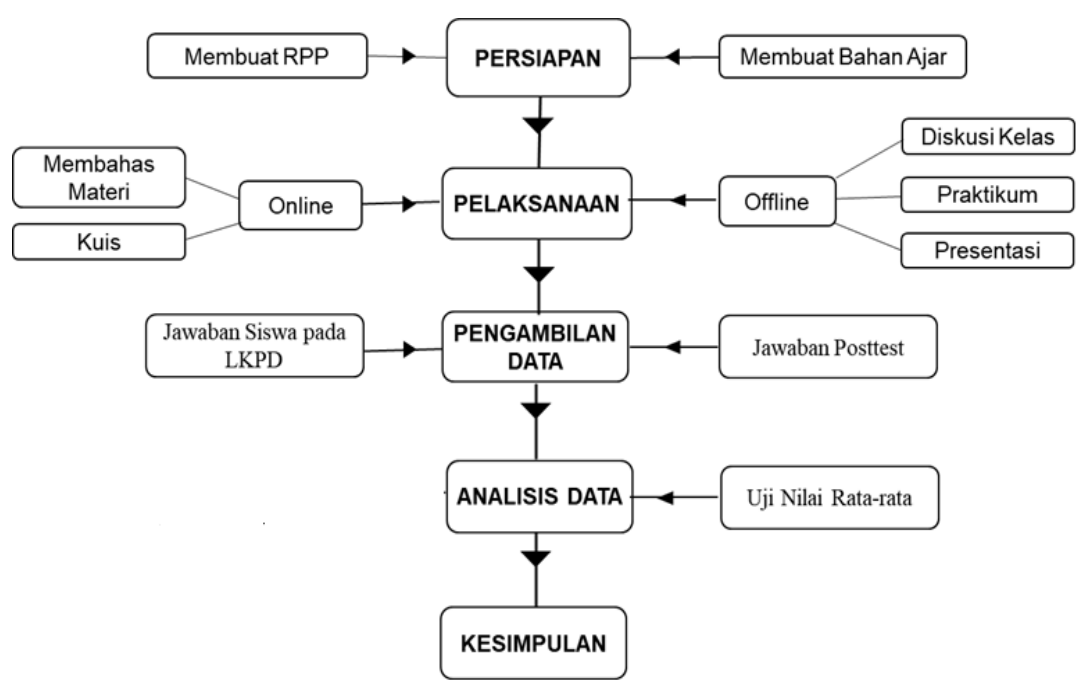

Gambar 1. Diagram Alur Penelitian

\subsection{Design Penelitian (Prancangan)}

Design penelitian bertujuan untuk merancang perangkat pembelajaran sebelum melakukan eksperimen, yaitu : a).Membuat Bahan Ajar (modul pembelajaran, LKPD, video, dan Memberikan Posttest). b). Penelitian soal, gambar yang sesuai dengan materi gerak lurus. c). Memasukan bahan ajar ke LMS ( Google Classroom). d). Menyiapkan alat dan bahan praktikum. e). Memberikan Quis dan Melakukan Praktikum

Penelitian ini dilaksanakan selama 2 bulan. Bahan dan alat yang digunakan pada saat melakukan eksperimen yaitu : Pewaktu ketik (Ticker timer), Papan seluncur, Mobil Mainan dan kereta dinamika, Catu daya (Power Supply), Penggaris, Gunting, Pita perekat (Sellotape), Kertas Karbo, Kertas grafik (Kertas Milimeter Blok). Penelitian ini menggunakan metode kuasi eksperimen dengan desain penelitian Post-test Only Control Design.

Populasi dalam penelitian ini adalah seluruh siswa-siswi kelas X MIPA SMA Negeri 37 Jakarta tahun ajaran 2019/2020. Sampel berjumlah 70 siswa yang terdiri atas 35 orang siswa kelas X MIPA 2 (kelas kontrol ) dan 35 siswa kelas X MIPA 4 ( kelas eksperimen). Teknik pengambilan sampel penelitian ini berdasarkan teknik Cluster random sampling terpilih dua buah sampel yaitu kelas X MIPA 2 sebagai kelas control kelas yang tidak mendapat perlakuan dan kelas X MIPA 4 yang memperoleh pembelajaran dengan model Flipped Classroom.

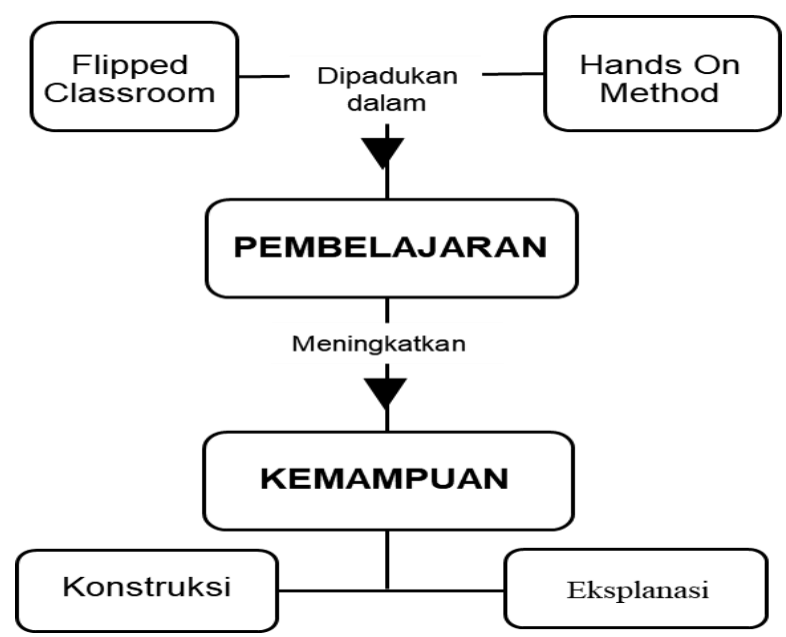

Gambar 2. Peta Konsep Penelitian 


\section{HASIL DAN PEMBAHASAN}

Sebelum mengajar seorang guru terlebih dahulu mempersiapkan alat dan bahan yang akan digunakan pada saat dikelas. Persiapan mengajar dilakukan dengan melihat tujuan pembelajaran dan pencapaian kompetensi sesuai dengan Rencana Pelaksanaan Pembelajaran (RPP) yang sudah di buat oleh pendidik. Materi gerak lurus pada mata pelajaran fisika terdapat 2 kali pertemuan dan 2 hari sebelum pertemuan materi sudah diberikan kepada peserta didik. Materi pembelajaran yang diberikan menggunakan LMS (Google Classroom) berupa Modul, Video, dan LKPD ( Lembar kerja peserta didik ) yang sesuai dengan topik pembelajaran yang akan dibahas.

Tabel 1. Nilai Rata-rata Posstest

\begin{tabular}{llll}
\hline No & Parameter & Kelas Eksperimen & Kelas Kontrol \\
\hline 1 & Jumlah Kelompok & 7 & 7 \\
2 & Nilai Terendah & 50 & 50 \\
3 & Nilai Tertinggi & 100 & 90 \\
4 & Rata-rata Nilai & 83,57 & 77,85 \\
\hline
\end{tabular}

Berdasarkan pada Tabel 1, nilai rata-rata posttest kelas eksperimen adalah 83,57 dan nilai rata-rata posttest kelas kontrol adalah 77,85. Dari nilai tersebut dapat di lihat bahwa kelas eksperimen megalami kenaikan nilai karena diberi perlakukan dari pada kelas kontrol yang tidak diberi perlakukan.

Selanjutnya dilakukan analisa soal untuk mengetahui perbandingan jawaban kelas Eksperimen dan Kontrol hasil perbandingan untuk soal nomor 1 dan 2 di kelas eksperimen banyak kelompok yang menjawab benar dibandingkan kelas kontrol, karena siswa bisa memahami konsep sehingga dapat menggambarkan grafik percobaan dengan benar. Begitu juga dengan soal nomor 3 lebih banyak kelompok mejawab soal dengan benar karena siswa dapat menjelaskan karakteristik gerak lurus dengan menganalisa grafik.

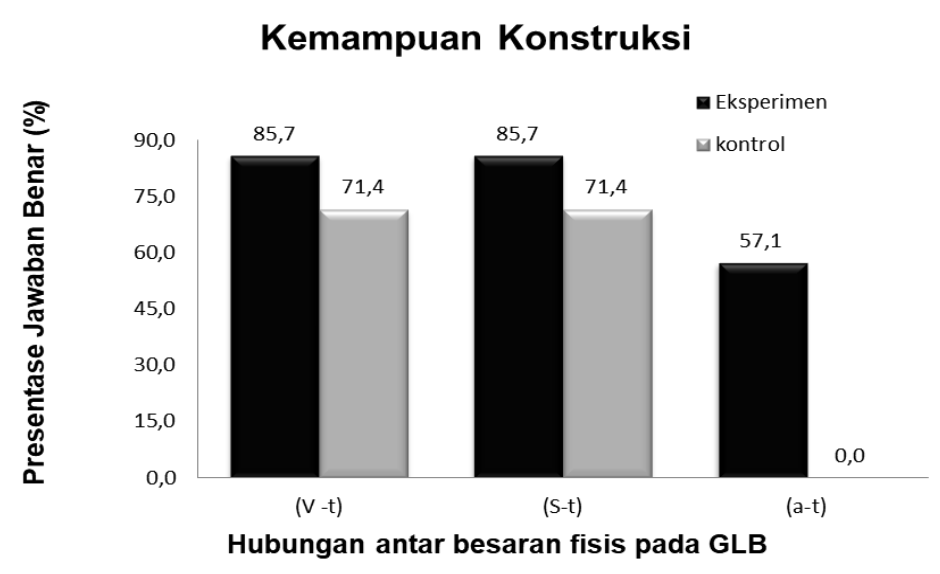

Gambar 3. Grafik Perbandingan Jawaban kelompok kelas Eksperimen dan Kontrol pada soal GLB

Gambar 3 memperlihatkan jawaban kelompok kelas eksperimen dan kontrol pada perbandingan jawaban siswa. Siswa dapat menggambarkan grafik hubungan antara (v-t), (s-t) dan (a-t) pada soal gerak lurus beraturan (GLB). Dari hasil jawaban dapat dilihat bahwa lebih besar selisih kelas eksperimen 85,7 dan kelas kontrol memiliki selisih paling kecil. Hal ini disebabkan karena kelas eksperimen memiliki kemampuan dalam mengkonstruksi. 


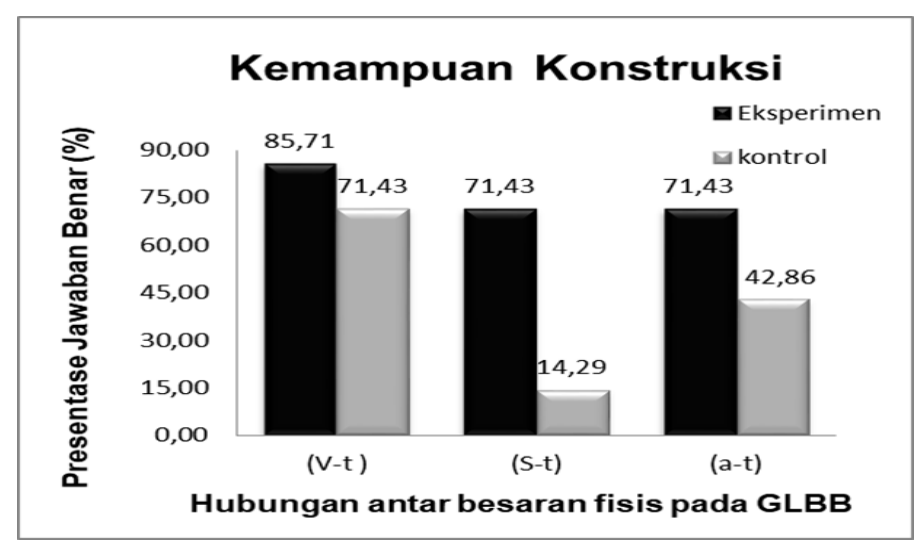

Gambar 4. Grafik Perbandingan Jawaban kelompok kelas Eksperimen dan Kontrol pada soal GLBB

Gambar 4 memperlihatkan jawaban kelompok kelas eksperimen dan kontrol pada perbandingan jawaban siswa. Siswa dapat menggambarkan grafik hubungan antara (v-t), (s-t) dan (a-t) pada soal gerak lurus berubah beraturan ( GLBB). Dari hasil jawaban dapat dilihat bahwa lebih besar selisih kelas eksperimen 85,7 dan kelas kontrol memiliki selisih paling kecil. Hal ini disebabkan karena kelas eksperimen memiliki kemampuan dalam mengkonstruksi.

Berdasarkan grafik hubungan antara besaran fisis GLB dan grafik hubungan antara besaran fisis GLBB diatas dapat disimpulkan bahwa kemampuan mengkonstruksi Siswa dalam kelompok pada kelas eksperimen selisih sebesar 85,7 \%. Hal ini dapat dilihat dari persentase hasil jawaban benar pada kelompok siswa dikelas eksperimen. Karena dalam pembelajaran yang mengintegrasikan PBL berupa eksperimen dan Flipped Classroom siswa dapat mengkonstruk sendiri pengetahuannya dan menghubungkannya dengan konsep dan eksperimen yang sudah dilakukan.

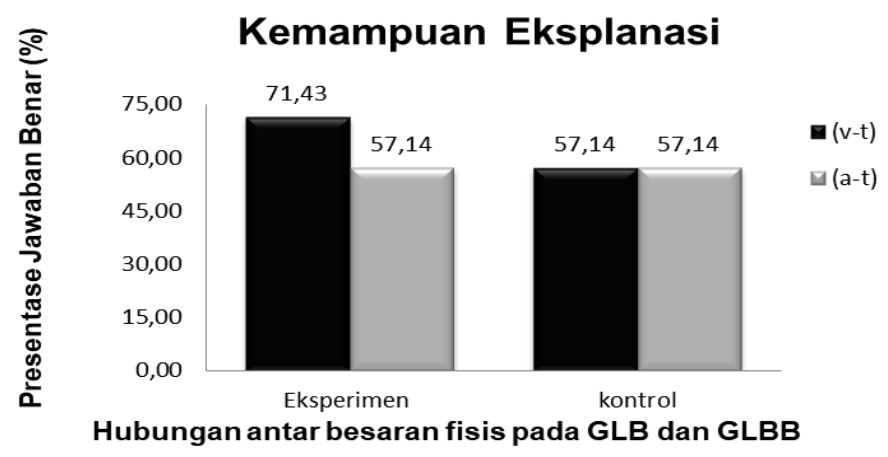

Gambar 5. Grafik Perbandingan Jawaban Hubungan Antar Besaran Fisis pada GLB dan GLBB

Berdasarkan grafik hasil penelitian hubungan antar Besaran Fisis pada GLB dan GLBB dapat disimpulkan bahwa kemampuan Eksplanasi siswa pada kelas Eksperimen juga meningkat dari pada kelas kontrol yaitu dari 57,14 \% sampai 71,43\%. Sedangkan dikelas kontrol tidak mengalami peningkatan hubungan antar Besaran Fisis pada GLB dan GLBB bernilai sama sebesar $57,14 \%$.

Penelitian ini dilakukan di Sekolah SMA Negeri 37 jakarta kelas X MIPA 2 sebagai kelas Kotrol dan X MIPA 4 sebagai kelas eksperimen. Berdasarkan LKPD (Lebar kerja peserta didik) yang diperoleh terlihat bahwa kemampuan siswa dalam Mengkonstruksi dan Mengeksplanasi 
Melalui Kombinasi Hands On Method dan Flipped Classroom pada Materi Gerak Lurus meningkat .

\section{KESIMPULAN}

Berdasarkan hasil penelitian diatas, dapat disimpulkan bahwa kombinasi Hands On Method dan Flipped Classroom dapat meningkatkan kemampuan konstruksi dan eksplanasi siswa. Hal tersebut dapat dilihat dari hasil nilai rata-rata posttest dikelas eksperimen sebesar 83,57 sedangkan nilai rata-rata posttest kelas kontrol sebesar 77,85. Demikian pula dilihat dari grafik kemampuan konsruksi dan eksplanasi. Hasil kemampuan konstruksi persentase jawaban siswa pada kelompok dikelas eksperimen meningkat sebesar 85,7 \% dan kemampuan ekplanasi dikelas eksperimen juga meningkat sebesar 71,43\%.

\section{SARAN}

Model pembelajaran ini dapat dilakukan di materi lainnya.

\section{DAFTAR PUSTAKA}

Antika, R. R. (2014). Proses Pembelajaran Berbasis Student Centered Learning (Studi Deskriptif di Sekolah Menengah Pertama Islam Baitul 'Izzah, Nganjuk ). BioKultur, 3(1), 251-263.

Dedy Setyawan, \& A. R. (2013). Eksplorasi Proses Konstruksi Pengetahuan Matematika Berdasarkan Gaya Berpikir. Jurnal Sainsmat, 2(2), 140-152.

Rusmania, N. (2015). Efektivitas Metode Hands On Minds On Disertai Herbarium Pada Materi Keanekaragaman Hayati Di Sma. Artikel penelitian, 151, 10-17. https://doi.org/10.1145/3132847.3132886

Widyastuti, N. S., Pujiastuti, P., \& Yogyakarta, U. N. (2014). Pengaruh Pendidikan Matematika Realistik Indonesia (PMRI) terhadap Pemahaman Konsep dan ... Nur Sri Widyastuti, Pratiwi Pujiastuti 183. Prima Edukasia, 2(2), 183-193.

Wiyono, K., \& Zakiyah, S. (2016). Pendidikan Fisika Pada Era Revolusi Industri 4 . O Di Indonesia. 1-14.

Wulansari, N. T., \& Sutrisna, I. P. G. (2018). Pengaruh Penerapan Model Pembelajaran Flipped Classroom Terhadap Hasil Belajar Kognitif Mahasiswa Keperawatan Dalam Materi Ajar Mikrobiologi. Jurnal Bioeducation, 5(2), 48-52. https://doi.org/10.29406/bio.v5i2.1034

Yanah, P. A., Nyeneng, I. D. P., \& Suana, W. (2018). Efektivitas Model Flipped Classroom pada Pembelajaran Fisika Ditinjau dari Self Efficacy dan Penguasaan Konsep Siswa. JIPFRI (Jurnal Inovasi Pendidikan Fisika Dan Riset Ilmiah), 2(2), 65-74. https://doi.org/10.30599/jipfri.v2i2.302 